\title{
Reduction of salivary tumor necrosis factor alpha levels in response to magic mouthwash with Curcuma xanthorriza in cancer patients undergoing chemotherapy
}

\author{
Irna SUFIAWATI ${ }^{1}{ }^{*}$, Indra GUNAWAN ${ }^{1}$, Indra WIJAYA ${ }^{2}$, Taofik RUSDIANA ${ }^{3}$, Anas SUBARNAS ${ }^{3}$ \\ 1 Department of Oral Medicine, Faculty of Dentistry, Universitas Padjadjaran, Bandung, Indonesia. \\ 2 Department of Internal Medicine, Faculty of Medicine, Universitas Padjadjaran, Bandung, Indonesia. \\ 3 Department of Pharmaceutics and Pharmaceutical Technology Chemistry, Faculty of Pharmacy, Universitas \\ Padjadjaran, Bandung, Indonesia. \\ * Corresponding Author. E-mail: irna.sufiawati@fkg.unpad.ac.id (I.S.); Tel. +62-22-25004985; ORCID No: 0000-0002- \\ 2506-5105.
}

Received: 15 November 2017 / Revised: 27 January 2018 / Accepted: 01 February 2018

\begin{abstract}
Tumor necrosis factor-alpha (TNF-a) is pro-inflammatory cytokine that play a key role in initiating and accelerating the development of oral mucositis in cancer patients undergoing chemotherapy. Mixed medication mouthwash called magic mouthwash has been widely used to prevent and treat oral mucositis. Curcuma xanthorriza is a traditional herbal medicine, which has shown anti-inflammatory, antibacterial, and antifungal effects. The aim of this study was to evaluate the effect of magic mouthwash with Curcuma xanthorriza on salivary TNF-a levels in cancer patients undergoing chemotherapy. The magic mouthwash formulation used in this study contains diphenhydramine, hydrocortisone, nystatin and dry curcuma extract. This study involved 60 cancer patients undergoing 5-Fluorouracil (5FU)-based chemotherapy who were assigned into two groups, each group consisted of 30 patients. Group 1 instructed for rinsing with magic mouthwash with Curcuma xanthorriza and group 2 rinsed with $\mathrm{NaCl} 0.9 \%$ as control group. Unstimulated whole saliva was collected before and after oral rinsing with mouthwashes. Salivary TNF-a levels were measured with enzyme linked immunosorbent assay (ELISA). Data were analyzed statistically with Wilcoxon and Chi square test. The result of this study showed a significant decrease in salivary TNF-a levels on both groups $(\mathrm{p}<0.05)$. In the study group, more patients were found with salivary TNF-a levels decreased $(74.2 \%)$ compared to control group $(53.5 \%)$ and showed significant difference statistically $(\mathrm{p}<0.05)$. The study concludes that magic mouthwash with Curcuma xanthorriza can reduce Salivary TNF-a levels and can be used as an alternative therapy for oral mucositisinduced chemotherapy.
\end{abstract}

KEYWORDS: Chemotherapy; Curcuma xanthorriza; magic mouthwash; salivary TNF-a.

\section{INTRODUCTION}

Oral mucositis is an inflammatory condition of the oral and oropharyngeal mucosa induce cytotoxic chemotherapy and/or radiotherapy that represent a major clinical problem in oncology. The prevalence of mucositis in patients undergoing standard-dose chemotherapy is approximately $40 \%$, and this ratio exceeds $50 \%$ in high-dose hemotherapy protocols [1]. Oral mucositis presents as confluent and deep ulcerations in its severest form. Pain associated with mucositis often impairs a patient's functional status and quality of life. In patients treated with chemotherapy alone or combined chemo-radiation regimens, the whole gastrointestinal tract may be affected. Weight loss is common, and patients may require gastrostomy or parenteral feeding. Severe oral mucositis may lead to dose reductions and unplanned interruptions of cancer therapies $[2,3]$.

Chemotherapy and radiation therapy activate the transcription factor nuclear factor-kB (NF-kB) in epithelial, endothelial and mesenchymal cells and macrophages, leading to the upregulation of genes and the production of pro- inflammatory cytokines, such as tumour-necrosis factor- $\alpha$ (TNF- $\alpha$ ) and interleukin-1 $\beta$ (IL-1 $\beta)$. These cytokines amplify the primary signal or may activate NF-kB in other cells, which results in the transcription of genes encoding mitogen- activated protein kinase (MAPK), cyclooxegenase 2 (COX2) and tyrosine-kinase signalling molecules. TNF-a also activates sphingomyelinase. So, its increased level in the tissue amplifies pro-apoptotic signals that are mediated by the ceramide pathway. In addition, both TNF- $\alpha$

How to cite this article: Sufiawati I, Gunawan I, Wijaya I, Rusdiana T, Subarnas A. Reduction of salivary tumor necrosis factor alpha levels in response to magic mouthwash with Curcuma xanthorriza in cancer patients undergoing chemotherapy. J Res Pharm. 2019; 23(1): 55-61. 
and IL-1 $\beta$ induce matrix metalloproteinase (MMP-1 and MMP-3) activation in cells of the epithelium and lamina propria, which ultimately results in tissue injury [4-6].

Magic mouthwash is commonly prescribed for conditions such as chemotherapy/radiation-induced mucositis, cancer sores, mouth pain, etc. The logic behind magic mouthwash is to combine ingredients with different potential mechanisms of action to treat a variety of oral conditions. The current guidelines for the treatment of oral mucositis suggest that compounded magic mouthwashes (with various combinations of viscous lidocaine, benzocaine, milk of magnesia, kaolin-pectin, chlorhexidine, or diphenhydramine) are not better than $\mathrm{NaCl} 0.9 \%$ solution in pain relief $[7,8]$. Curcuma xanthorrhiza is also known as Javanese Turmeric or Temu Lawak. C. xanthorrhiza belongs to the family Zingiberaceae. The root contains two classes of characteristic constituents curcuminoids (1-2\%) and volatile oil (3-12\%). Curcuma (Zingiberaceae) is a large genus of rhizomatous herbs distributed in tropical and subtropical regions especially in India, Thailand, the Malay Archipelago, Indochina, and Northern Australia. Many species have been cultivated, and their powdered rhizomes have been widely used to add flavors in native dishes and as ingredients in many traditional medicines to treat various ailments. The more popular and economically more important species, C. Domestica L. and C. xanthorrhiza Roxb., are more widely used as condiments than for their medicinal purposes. Curcuma xanthorriza has anti-inflammation, antimicroba, antifungal effects. Curcuma xanthorrhiza extract is used as natural sanitizer agent for antimicrobial activity against potential pathogenic bacteria [9-12]. In this present study, we investigated the effect of magic mouthwash with Curcuma xanthorriza on salivary TNF-a levels in cancer patients undergoing chemotherapy in comparison sodium chloride $0.9 \%$ solution $(\mathrm{NaCl}$ $0.9 \%)$.

\section{RESULTS}

This study enrolled 61 patients under 5-Fluorouracil (5-FU)-based chemotherapy who were divided into magic mouthwash group of 31 patients and control group of 30 patients. Patients characteristic are shown on Table 1. Plot diagram for salivary TNF-a levels before and after rinsing with magic mouthwash and $\mathrm{NaCl} 0.9 \%$ is presented in Figure 1. The result analysis on Table 2 shows that significant differences statistically $(\mathrm{p}<0.05)$ on TNF- $\alpha$ salivary level median before rinsing with magic mouthwash $(4.761 \mathrm{pg} / \mathrm{ml})$ and after rinsing with magic mouthwash $(4.392 \mathrm{pg} / \mathrm{ml})$ and also on TNF-a salivary level median before rinsing with $\mathrm{NaCl} 0.9 \%$ $(5.843 \mathrm{pg} / \mathrm{ml})$ and after rinsing with $\mathrm{NaCl} 0.9 \%(5.048 \mathrm{pg} / \mathrm{ml})$. The result analysis in Table 3 shows statistically significant differences $(\mathrm{p}<0.05)$ on decreased TNF-a salivary level percentage after rinsing with magic mouthwash (74.2\%) higher that after rinsing with $\mathrm{NaCl} 0.9 \%$ (53.3\%).

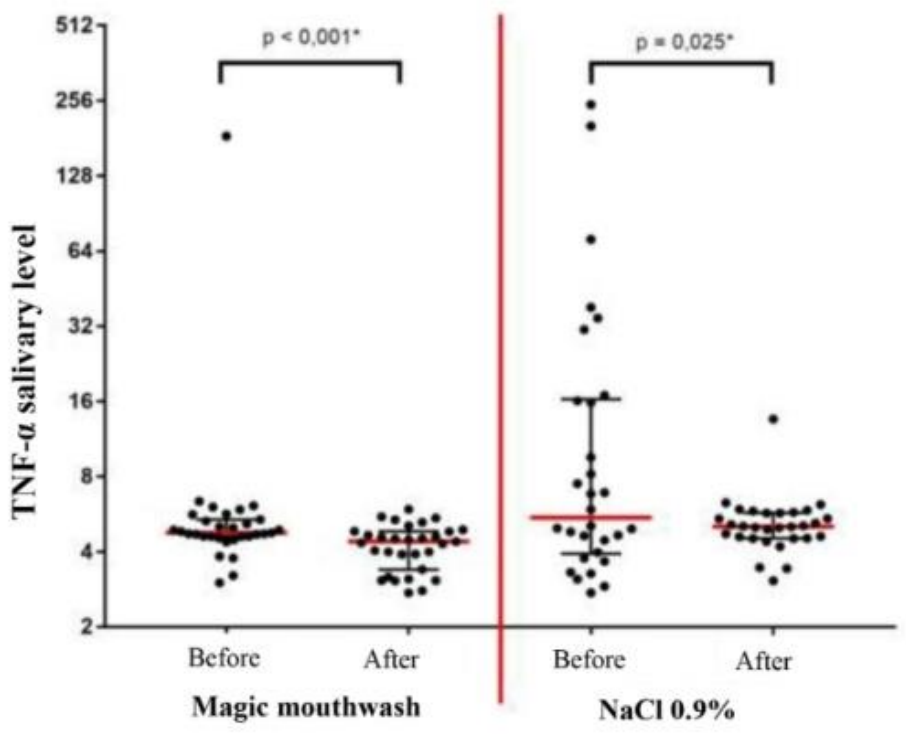

Figure 1. Plot diagram of salivary TNF-a levels before and after rinsing with magic mouthwash and $\mathrm{NaCl}$ $0.9 \%$ 
Table 1. Patient characteristics

\begin{tabular}{lcc}
\hline Characteristics & $\begin{array}{c}\text { MWW group } \\
\mathbf{n}=\mathbf{3 0}\end{array}$ & $\begin{array}{c}\text { Normal saline group } \\
\mathbf{n}=\mathbf{3 0}\end{array}$ \\
\hline Sex, $\mathbf{n}(\%)$ & & \\
$\quad$ Male & $8(25.8)$ & $2(6.7)$ \\
$\quad$ Female & $22(74.1)$ & $28(93.3)$ \\
Age (year) & & \\
$\quad$ Range 21-71 & & \\
$\quad$ Mean \pm SD & $48 \pm 11$ & $47 \pm 12$ \\
Cancer type, $\mathbf{n}$ (\%) & & \\
Ca. Mammae & $25(83.9)$ & $25(83.3)$ \\
Ca. Nasopharynx & $3(9.7)$ & $2(6.7)$ \\
Ca. Cervix st. 1 & $0(0.0)$ & $2(6.7)$ \\
Ca. Colon & $1(3.2)$ & $1(3.3)$ \\
Ca. Anus & $1(3.2)$ & $0(0.0)$ \\
\hline
\end{tabular}

Table 2. Salivary TNF-a levels before and after rinsing with magic mouthwash compared to $\mathrm{NaCl} 0.9 \%$

\begin{tabular}{lccccc}
\hline & & $\begin{array}{c}\text { Before rinsing } \\
\text { Median }\end{array}$ & $\begin{array}{c}\text { After rinsing } \\
\text { Median }\end{array}$ & $\begin{array}{c}\text { Median } \\
\text { differencs } \\
(\mathbf{9 5 \%} \mathbf{C I})\end{array}$ & p value \\
\hline $\begin{array}{l}\text { Salivary } \\
\text { TNF- } \boldsymbol{\alpha}\end{array}$ & $\mathbf{M M W}$ & $\begin{array}{c}4,761 \\
(3,005-184,700)\end{array}$ & $\begin{array}{c}4,392 \\
(2,738-5,911)\end{array}$ & $\begin{array}{c}0,715 \\
(0,230-1,392)\end{array}$ & $0,001^{*}$ \\
\cline { 2 - 6 } $\begin{array}{l}\text { level } \\
(\mathbf{p g} / \mathbf{m l})\end{array}$ & $\mathbf{N a C L}$ & 5,483 & 5,048 & 0,402 & \\
& $\mathbf{0 , 9} \%$ & $(2,742-247,100)$ & $(3,060-13,580)$ & $(-0,358-4,836)$ & $0,025^{*}$ \\
\hline
\end{tabular}

Note : wilcoxon test, ${ }^{*} \mathrm{p}<0,05$

Table 3. Differences in salivary TNF-a levels before and after rinsing with magic mouthwash compared to $\mathrm{NaCl} 0.9 \%$

\begin{tabular}{ccccc}
\hline $\begin{array}{c}\text { The changes in } \\
\text { salivary TNF- } \alpha \text { level }\end{array}$ & $\mathbf{n}$ & $\mathbf{M M W}$ & $\mathbf{N a C l ~ 0 , 9 \%}$ \\
$\mathbf{n = 3 0 3 0}$ & p value \\
\hline $\begin{array}{c}\text { Decreased salivary } \\
\text { TNF- } \alpha \text { level }\end{array}$ & 38 & $23(74,2)$ & $16(53,3)$ & $0,045^{*}$ \\
$\begin{array}{c}\text { Increase salivary } \\
\text { TNF- } \alpha \text { level }\end{array}$ & 22 & $7(25,8)$ & $14(46,7)$ & \\
\hline
\end{tabular}

Note : Chi square test, ${ }^{*} \mathrm{p}<0,05$

\section{DISCUSSION}

The chemotherapy drugs induce the death of the basal epithelial cells, which may occur by the generation of free radicals. These free radicals activate second messengers that transmit signals from receptors on the cellular surface to the inner cell environment, leading to up-regulation of pro-inflammatory cytokines, tissue injury, and cell death. The pro-inflammatory cytokines produced by macrophages, such as TNF- $\alpha$, amplify the mucosal injury; the production of these pro-inflammatory cytokines can also be stimulated by a superimposed infection of the ulcerated areas of the mucosa [13-15]. TNF-a is not usually detectable in healthy individuals, but elevated serum and tissue levels are found in inflammatory and infectious conditions and serum levels correlate with the severity of infections. Although the cells of the monocyte/macrophage lineage are the main source of TNF-a in inflammatory disease, a wide range of cells can produce TNF- $a$, including mast cells, T and B lymphocytes, natural killer (NK) cells, neutrophils, endothelial cells, smooth and cardiac muscle cells, fibroblasts and osteoclasts $[16,17]$ 
TNF- $\alpha$ is a key pro-inflammatory cytokine that causes tissue damage, and the release of TNF-a may initiate and accelerate the development of oral mucositis $(\mathrm{OM})$. It has been reported in several human studies that the levels of pro-inflammatory cytokines are increased in the blood and saliva of patients during cancer treatment. Other studies using animal models have shown evidence of changes in the serum level and tissue expression of nuclear factor $\mathrm{k}-\mathrm{B}$ and the pro-inflammatory cytokines (TNF- $\alpha$, interleukin (IL)-1 $\beta$ and IL-6) following administration of chemotherapeutic drugs $[18,19]$.

This study shows that salivary TNF-a level median before and after rinsing with magic mouthwash with Curcuma xanthorrhiza were significantly lower compared to before and after rinsing with $\mathrm{NaCl} 0.9 \%$ $(p<0.05)$. The magic mouthwash used in this study contains diphenhydramine as a topical analgesic, hydrocortisone as an anti-inflammation, nystatin as an anti-fungal and dry curcuma extract as a preservative agent. Corticosteroids have an anti-inflammatory effect, which is mainly related to the inhibition of transcription of several pro-inflammatory cytokines/mediators. Other factors contributing to their antiinflammatory and immunosuppressant properties include the apoptosis of basophils and the inhibition of adhesion molecule expression on the surface of endothelial cells [20].

The naturally occurring and synthetic corticosteroids act by entering the cell by diffusion across the plasma membrane and binds reversibly to glucocorticoid receptors (GR) that is thought to be available in most, if not all, nucleated cells. GR is expressed in almost all tissues although tissue and cell cycle-specific regulation of GR levels have been reported. The expression pattern of GR shows that the receptor is distributed ubiquitously, but is more prevalent in hepatic, nervous system, and muscular tissues. Even though GR is widely distributed, cellular sensitivity to glucocorticoids is complex and dependent on many factors. Consequent to this interaction, the steroid-ligand complex alters its conformation, exposing a DNAbinding domain, and then migrates to the nucleus where it binds to a site on the chromatin. The complex regulates transcription of specific gene sequences into mRNA. This leaves the nucleus to bind to ribosomes where their nucleotide sequences are translated into corresponding amino-acid sequences of proteins and specific enzymes [21-23].

Topical application of steroids reduces the effect of chemo-attractants on polymorphoneutrophils $(\mathrm{PMN})$ and monocyte aggregation, reduces migration and phagocytosis of PMN, and reverses the dilatation and increased permeability of the small vessels at the site of application. This last property is the basis of the vasoconstriction assay for assessing corticosteroid potency. In addition, corticosteroids have an antimitotic effect on several cell types that could be the basis for at least some of their activity against lichen planus. This activity seems to be non-cell specific; a reduction in RNA synthesis has been demonstrated in both normal and psoriatic skin following exposure to corticosteroids [21]. Aggarwal et al., reported that curcumin has the potential to inhibit NF-кB. The expression of several genes that are regulated by NF-kB has also shown to be suppressed by curcumin [24]. These include cell surface adhesion molecules, chemokines, TNF, MMP-9, COX2, and nitric oxide synthase (NOS). Since these genes are critical regulators of inflammation, the suppression of expression of these genes explains the anti- inflammatory effects of curcumin $[25,26]$.

$\mathrm{NaCl} 0.9 \%$ (sodium chloride $0.9 \%$ solution) is a harmless bland isotonic oral rinse which has been shown to be beneficial in maintaining appropriate oral hygiene due to its safety, lowest toxicity and physiologic properties [27]. There were several studies on the preventive effect of $\mathrm{NaCl} 0.9 \%$ on oral mucositis in chemotherapy, radiotherapy and/or hematopoietic stem cell transplantation (HSCT) patients [28], however few studies have assessed its effect on prevention of mucositis resulting from chemotherapy [28,29]. $\mathrm{NaCl}$ $0.9 \%$ showed inferior effect on preventing chemotherapy induced mucositis compared to chlorhexidine and cryotherapy [28]. Another study showed that $\mathrm{NaCl} 0.9 \%$ was less effective in preventing chemotherapyinduced mucositis in comparison to honey plus $\mathrm{NaCl} 0.9 \%$ and placebo groups [29]. The Results and Discussion sections may be combined. The purpose of the discussion is to interpret significance of the results and to relate them to existing knowledge in the field in as clear and brief a fashion as possible. Information given elsewhere in the manuscript should not be repeated in the discussion. Extensive reviews of the literature should be avoided.

\section{CONCLUSION}

Salivary TNF-a levels were significantly more decreased in cancer patients undergoing chemotherapy after rinsing with magic mouthwash with Curcuma xanthorrhiza compared to $\mathrm{NaCl} 0.9 \%$ suggesting that it has the potential as an alternative treatment for chemotherapy-induced oral mucositis. 


\section{MATERIALS AND METHODS}

This research was conducted at Hematology-Oncology Division, Internal Medicine Department, Dr. Hasan Sadikin Hospital Bandung, Indonesia, and the study was approved by The Health Research Ethics Committee, Faculty of Medicine, Padjadjaran University (the number/ID of the approval 366/UN6.C10/PN/2017). Selected sixty participants of the study subjects all received 5-FU based chemotherapy at doses of $600 \mathrm{mg} / \mathrm{m} 2$ based on patients' body surface area (BSA), once in an interval 21 days, 6 times. They were divided into 2 groups, study and control groups. The study group was given magic mouthwash and the control group was given $\mathrm{NaCl} 0.9 \%$. Unstimulated whole saliva samples were collected from those patients. These mouthwashes were given after the first collection of saliva samples. Unstimulated whole saliva samples were collected again three weeks (21 days) after the first saliva samples have been collected. salivary TNF- $\alpha$ levels were measured with enzyme linked immunosorbent assay (ELISA). TNF-a ELISA kit were purchased from Elabscience ${ }^{\circledR}$ ELISA Kit. The instruments used for ELISA are a microplate reader (RT-6500; Rayto Life and Analytical Sciences Co., Ltd, Shenzhen, China), and PW-40 microplate washer (Bio-Rad Laboratories, Inc. France).

The magic mouthwash formulation used in this study contains $600 \mathrm{mg}$ Diphenhydramine, $60 \mathrm{mg}$ Hydrocortisone, $1 \mathrm{~g}$ Nystatin and $16 \mathrm{mg}$ dry curcuma extract, $480 \mathrm{mg} \mathrm{Na}$ - CMC (Sodium Carboxymethylcellulose) as suspending agent and $240 \mathrm{ml}$ distilled water given $10 \mathrm{ml}$ swish and spit twice a day.

The dry curcuma extract used in this study were purchased from PT. Konimex Pharmaceutical Laboratories, Jakarta, Indonesia. Hydrocortisone powder were purchased from Sigma-aldrich catalogue number PHR1014. Dyphenhydramine powder were purchased from Acros organics catalogue number AC350850000, AC350850250, AC350851000. Nystatin powder were purch from Xabcbiotech. Result data were analyzed statistically with Wilcoxon and Mann-Whitney test $(\mathrm{p}<0.05)$.

Acknowledgements: The authors would like to acknowledge the members of the Clinical Pathology Laboratory of Hasan Sadikin Hospital, Bandung, West Java, Indonesia for generous assistance, data collection and their laboratory help. This project was supported by the Academic Leadership Grant (ALG) Universitas Padjadjaran.

Author contributions: Concept - I.S.; Design - I.S., I.G.; Supervision - I.S., I.W., T.R., A.S.; Resource - A.S.; Materials I.S., I.G., I.W.; Data Collection and/or Processing - I.S., I.G., I.W., T.R.; Analysis and/or Interpretation - I.S., I.G., I.W., T.R., A.S.; Literature Search - I.S., I.G.; Writing - I.S., I.G., I.W., T.R.; Critical Reviews - I.S., I.W., T.R., A.S.

Conflict of interest statement: The authors declared no conflict of interest.

\section{REFERENCES}

[1] Baydar M, Dikilitas M, Sevinc A, Aydogdu I. Prevention of Oral Mucositis Due to 5-Fluorouracil Treatment with Oral Cryotherap. J Natl Med Assoc. 2005; 97(8): 1161-1164.

[2] Al-Ansari S, Zecha J a. EM, Barasch A, de Lange J, Rozema FR, Raber-Durlacher JE. Oral Mucositis Induced By Anticancer Therapies. Curr Oral Heal Reports. 2015; 2(4):202-211.

[3] Elting LS, Keefe DM, Sonis ST, Garden AS, Spijkervet FKL, Barasch A, Tishler RB, Canty TP, Kudrimoti MK, VeraLlonch M, for the Burden of Illness Head and Neck Writing Committee. Patient-reported measurements of oral mucositis in head and neck cancer patients treated with radiotherapy with or without chemotherapy. Cancer. 2008;113(10): 2704-2713.

[4] Sonis ST. The pathobiology of mucositis. Nat Rev Cancer. 2004;4(4):277-84.

[5] Sonis ST. Mucositis: The impact, biology and therapeutic opportunities of oral mucositis. Oral Oncol. Elsevier Ltd; 2009; 45(12): 1015-1020.

[6] Ben Salem M, Affes H, Athmouni K, Ksouda K, Dhouibi R, Sahnoun Z, Hammami S, Zeghal KM. Chemicals Compositions, Antioxidant and Anti-Inflammatory Activity of Cynara scolymus Leaves Extracts, and Analysis of Major Bioactive Polyphenols by HPLC. Evidence-based Complement Altern Med. 2017;2017.

[7] Rubenstein EB, Peterson DE, Schubert M, Keefe D, McGuire D, Epstein J, Elting LS, Fox PC, Cooksley C, Sonis CT. Clinical practice guidelines for the prevention and treatment of cancer therapy-induced oral and gastrointestinal mucositis. Cancer. 2004;100(9 Suppl):2026-2046.

[8] Letter P. Magic Mouthwash. Ther Res Cent. 2007;23(7): 230703. https://mercypharmacy.wikispaces.com /file/view/MAGIC+MOUTHWASH.pdf (accessed April 20, 2017). 
[9] Galen E Van, Kroes B. Assessment report on Curcuma xanthorrhiza Roxb. ( C. xanthorrhiza D. Dietrich ), rhizoma. European Medicines Agency. 2014. http://www.ema.europa.eu/docs/en_GB/document_library/Herbal__HMPC_assessment_report/2014/05/WC500166364.pdf (accessed July 18, 2017).

[10] Jantan I, Saputri FC, Qaisar MN, Buang F. Correlation between Chemical Composition of Curcuma domestica and Curcuma xanthorrhiza and Their Antioxidant Effect on Human Low-Density Lipoprotein Oxidation. Evidence-Based Complement Altern Med. 2012;2012:1. http://dx.doi.org/10.1155/2012/438356.

[11] Lew KF, Goh GL, Son R, Rukayadi Y. Effect of Javanese turmeric (Curcuma xanthorrhiza Roxb.) extract on natural microflora of oyster mushroom (Pleurotus sajur-caju) and its sensory acceptability. Int Food Res J. 2015;22(6):24462451. http://www.ifrj.upm.edu.my/22\%20(06)\%202015/(38).pdf

[12] Halim MRA, Tan MSMZ, Ismail S, Mahmud R. Standardization and Phytochemical Studies of Curcuma Xanthorrhiza Roxb. Int J Pharm Pharm Sci. 2012;4(3):606-610. http:// www.ijppsjournal.com/Vol4Issue3/4174.pdf

[13] Trucci VM, Veeck EB, Morosolli AR. Current strategies for the management of oral mucositis induced by radiotherapy or chemotherapy. Rev Odonto Cienc. 2009;24(3):309-314.

[14] Sultani M, Stringer AM, Bowen JM, Gibson RJ. Anti-Inflammatory Cytokines: Important Immunoregulatory Factors Contributing to Chemotherapy-Induced Gastrointestinal Mucositis. Chemother Res Pract. 2012;2012:1-11.

[15] Lalla R V., Sonis ST, Peterson DE. Management of Oral Mucositis in Patients with Cancer. Dent Clin North Am. 2008;52(1):1-17.

[16] Bradley J. TNF-mediated inflammatory disease. J Pathol. 2008;214:149-160.

[17] Aggarwal BB, Kohr WJ, Hass PE, Moffat B, Spencer SA, Henzel WJ, et al. Human tumor necrosis factor. Production, purification, and characterization. J Biol Chem. 1985;260(4):2345-2354.

[18] Sakamoto K, Takeda S, Kanekiyo S, Nishiyama M, Kitahara M, Ueno T, Yamamoto S, Yoshino S, Hazama S, Okayama $\mathrm{N}$, Nagano H. Association of tumor necrosis factor-a polymorphism with chemotherapy-induced oral mucositis in patients with esophageal cancer. Mol Clin Oncol. 2017;6(1):125-129.

[19] Steer JH, Kroeger KM, Abraham LJ, Joyce DA. Glucocorticoids Suppress Tumor Necrosis Factor-Alpha Expression By Human Monocytic THP-1 Cells By Suppressing Transactivation Through Adjacent NF-kB And C-Jun-Activating Transcription Factor- 2 Binding Sites İn The Promoter. J Biol Chem. 2000;275(24):18432-18440.

[20] Baeck M, Marot L, Pilette C, Tennstedt D, Goossens A. Allergic hypersensitivity to topical and systemic corticosteroids : a review. 2009;64(7):978-994.

[21] Thorburn DN, Ferguson MM. Topical corticosteroids and lesions of the oral mucosa. Adv Drug Deliv Rev. 1994;13:135-49.

[22] Oakley robert H, Cidowski JA. The Biology of the Glucocorticoid Receptor: New Signaling Mechanisms in Health and Disease. J Allergy Clin Immunol. 2013;132(5):1033-1044.

[23] Lu NZ, Wardell SE, Burnstein KL, Defranco D, Fuller PJ, Giguere V, Hochberg RB, McKay L, Renoir JM, Weigel NL, Wilson EM, McDonnell DP, Cidlowski JA. International Union of Pharmacology . LXV . The Pharmacology and Classification of the Nuclear Receptor Superfamily: Glucocorticoid, Mineralocorticoid, Progesterone, and Androgen Receptors. Pharmacol Rev. 2006;58(4):782-797.

[24] Aggarwal BB. Anticancer Potential Of Curcumin: preclinical and clinical studies. Anticancer Res. 2003;23(1A):363398.

[25] van't Land B, Blijlevens NM a, Marteijn J, Timal S, Donnelly JP, de Witte TJ, M'Rabet L. Role of curcumin and the inhibition of NF-kappaB in the onset of chemotherapy- induced mucosal barrier injury. Leukemia. 2004;18(2):276284.

[26] Patil K, Guledgud MV, Kulkarni PK, Keshari D, Tayal S. Use of Curcumin Mouthrinse in Radio-Chemotherapy Induced Oral Mucositis Patients: A Pilot Study. J Clin Diagn Res. 2015;9(8):ZC59-ZC62.

[27] McGuire DB, Fulton JS, Park J, Brown CG, Correa ME, Eilers J, Elad S, Gibson F, Oberle-Edwards LK, Bowen J, Lalla RV. Systematic Review Of Basic Oral Care For The Management Of Oral Mucositis İn Cancer Patients. Support Care Cancer. 2013;21(11):3165-3177.

[28] Sorensen JB, Skovsgaard T, Bork E, Damstrup L, Ingeberg S. Double-Blind, Placebo-Controlled, Randomized Study Of Chlorhexidine Prophylaxis For 5-Fluorouracil-Based Chemotherapy-İnduced Oral Mucositis With Nonblinded Randomized Comparison To Oral Cooling (Cryotherapy) in Gastrointestinal Malignancies. Cancer. 2008;112(7):16001606. 
[29] Sedighi I, Molaee S, Amanati A, Khoeinipourfar H, Nouri S. Antimicrobial Activity of Natural Honey: Topical Application of Pure Natural Honey in Prevention of Chemotherapy Induced Oral Mucositis. J Compr Ped. 2013;4(3):138-142.

This is an open access article which is publicly available on our journal's website under Institutional Repository at http://dspace.marmara.edu.tr. 